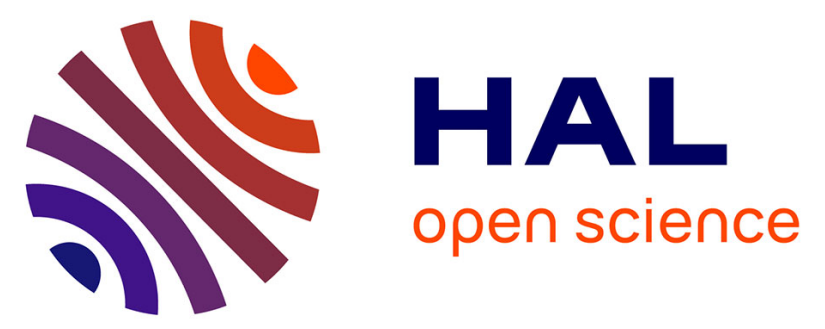

\title{
Chiral imines on the wave: reactivity of tert-butyl acrylate and stereoselectivity determination using NMR in liquid crystals
}

Lucie Vandromme, Li Chen, Lai Wei, Franck Le Bideau, André Loupy, Philippe Lesot, Olivier Lafon, Elise Tran Huu Dau, Pierre Chaminade, Françoise Dumas

\section{To cite this version:}

Lucie Vandromme, Li Chen, Lai Wei, Franck Le Bideau, André Loupy, et al.. Chiral imines on the wave: reactivity of tert-butyl acrylate and stereoselectivity determination using NMR in liquid crystals. MOL2NET, International Conference on Multidisciplinary Sciences, 2015, SCIForum, France. pp.1-18, 10.3390/MOL2NET-1-a003 . hal-02314359

\section{HAL Id: hal-02314359 \\ https://hal.science/hal-02314359}

Submitted on 14 Oct 2019

HAL is a multi-disciplinary open access archive for the deposit and dissemination of scientific research documents, whether they are published or not. The documents may come from teaching and research institutions in France or abroad, or from public or private research centers.
L'archive ouverte pluridisciplinaire HAL, est destinée au dépôt et à la diffusion de documents scientifiques de niveau recherche, publiés ou non, émanant des établissements d'enseignement et de recherche français ou étrangers, des laboratoires publics ou privés. 


\title{
Chiral Imines on the Wave: Reactivity of tert-Butyl Acrylate and Stereoselectivity Determination Using NMR in Liquid Crystals
}

\section{Lucie VANDROMME ${ }^{1}$, Li CHEN ${ }^{1}$, Lai WEI ${ }^{1}$, Franck LE BIDEAU ${ }^{1}$, André LOUPY ${ }^{2}$, Philippe LESOT ${ }^{3}$, Olivier LAFON ${ }^{3}$, Elise TRAN HUU DAU ${ }^{4}$ Pierre CHAMINADE $^{5}$ and Françoise DUMAS 1,*}

1 BioCIS, UMR CNRS 8076, Université Paris Saclay, School of Pharmacy, Université Paris-Sud, 5, rue J.-B. Clément, F-92296 Châtenay-Malabry, France; E-Mails: lucie.vandromme@free.fr (L. V.); li.chen1@u-psud.fr (L. C.); lai.wei@u-psud.fr (L. W.); franck.lebideau@u-psud.fr (F. L. B.); francoise.dumas@u-psud.fr (F.D.);

2 LRSSS, UMR CNRS 8615, Université Paris Saclay, UFR de Sciences, Université Paris-Sud, ICMMO, Bât. 410, F-91405 Orsay, France; E-Mail: andre.loupy@cegetel.net (A.L.);

3 Laboratoire de RMN en Milieu Orienté, CNRS UMR 8182, ICMMO, Bât. 410, Université Paris Saclay, UFR de Sciences, 91405 Orsay cedex, France. E-mail: philippe.lesot@u-psud.fr

4 ICSN, UPR CNRS 2301,1 avenue de la Terrasse, F-91190 Gif sur Yvette, France; E-Mail: elise.tran@icsn.cnrs-gif.fr.

5 Lip(Sys)2, EA 4041, Université Paris Saclay, School of Pharmacy, Université Paris-Sud, 5, rue J.B. Clément, F-92296 Châtenay-Malabry, France ; Email : pierre.chaminade@u-psud.fr

* Author to whom correspondence should be addressed; E-Mail: francoise.dumas@u-psud.fr; Tel.: +33-146-835-563.

Published: 4 December 2015

\begin{abstract}
In connection with synthetic applications, we have foreseen to study the reactivity of the poorly reactive tert-butyl acrylate electrophile with chiral imines of unsymmetrical ketones, using conventional or microwave flash heating under carefully controlled reaction conditions in order to develop a selective and efficient access to the corresponding Michael adducts in which a created stereogenic quaternary carbon center was fully stereocontrolled. Depending on the conditions, either a keto ester or a lactam were obtained. A good correlation was obtained between experiment and theoretical calculations. The stereoselectivity of the process (e>95\%) was determined using natural abundance ${ }^{13} \mathrm{C}-\left\{{ }^{1} \mathrm{H}\right\}$ NMR in a chiral polypeptide liquid crystal. The scope of the reaction was screened using a set of electrophilic alkenes giving Michael adducts in good yield and similar high enantiocontrol.
\end{abstract}


Keywords: Aza-ene process, Asymmetric Michael reaction, Enamine activation, Unsymmetrical ketones, tert-Butyl acrylate, Quaternary carbon center, chiral polypeptide, liquid crystal, ${ }^{13} \mathrm{C}-\left\{{ }^{1} \mathrm{H}\right\}$ NMR, MW assisted synthesis.

\section{Introduction}

Although a broad range of methods able to generate new carbon-carbon bonds exists, the establishment of quaternary carbon centres in the proper configuration is among the most restrictive in organic synthesis. ${ }^{1}$ Since forty years, the asymmetric Michael addition of chiral imines (AMACI) under neutral conditions has attracted widespread attention as a versatile carbon-carbon bond-forming method, leading to Michael adducts with high levels of regio- and stereocontrol. ${ }^{2}$ Such Michael adducts featuring a stereogenic tetrasubstituted carbon center are useful synthons for the asymmetric synthesis of a variety of bioactive compounds. ${ }^{3}$ Besides its remarkable efficiency due to a concerted aza-ene type mechanism, ${ }^{4}$ the reaction tolerates a large

\section{Results and Discussion}

As a part of our program directed at exploring the scope of the AMACI, and in connection with synthetic applications for which an orthogonal ester protection cleavable in acidic medium was desired in the Michael adduct, we have foreseen to study the reactivity of tert-butyl acrylate $\mathbf{3}$ with chiral imine 2a derived from 2-methylcyclopentanone 1a. Although considerable attention has recently been focused on organocatalytic asymmetric transformations as efficient and convenient methodologies owing to their environmentally friendly characteristics, none of them address the reactivity of bulky electrophiles in this reaction. ${ }^{9}$ Prior to engage in such studies, and because the chiral inductor is available at low price and easily recovered without loss of optical activity at the end of the process, we first analyze the stoichiometric transformation. Due to the steric hindrance of the variability in both carbonyl compounds and Michael acceptors, with some limitations for hindered systems for which high pressure activation is required..$^{5}$ Moreover, in the context of improved reaction efficiency, clean processes and short reaction times are desired. In this respect, $\mu \mathrm{W}$ is an efficient way of promoting organic transformations, mainly in solvent-free systems. Thus, interest in $\mu \mathrm{W}$ assisted organic reactions has recently considerably increased. ${ }^{6}$ Nevertheless, little attention has been devoted to the $\mu \mathrm{W}$ effects on selectivity, ${ }^{7}$ particularly for asymmetric Michael reactions. ${ }^{8}$ Herein, we describe our investigation of the reactivity of chiral imines with hindered tert-butyl acrylate and related electrophiles under microwave activation.

acceptor, we have turned to use microwave irradiation $(\mu \mathrm{W})$ under carefully controlled reaction conditions, in order to develop a simple and efficient access to Michael adduct $5 \mathbf{a}$ and the derived keto-acid $\mathbf{6}$ and compared this method to conventional heating $(\Delta)$ (Scheme 1).

In general, the AMACI is carried out from the intermediary chiral imine and the electrophile, in the absence of solvent, at room temperature or using moderate $\Delta$ (up to $80{ }^{\circ} \mathrm{C}$ ) as the regio- and stereocontrol of this reaction are only slightly sensitive to heat. $^{2}$ When the reaction was performed at $25{ }^{\circ} \mathrm{C}$ for 7 days, the conversion was not complete and 15\% yield of Michael adduct 5a was obtained upon hydrolysis (Table 1, entry 1). Thus, due to its bulkiness, tert-butyl acrylate 3 reacts much slower than its methyl counterpart. ${ }^{10}$ At $60{ }^{\circ} \mathrm{C}$, all the imine $2 \mathbf{a}$ was consumed in one day; however, side 
polymerization reactions resulted in a modest $58 \%$ yield of adduct 5 (Table 1, entry 2 ).

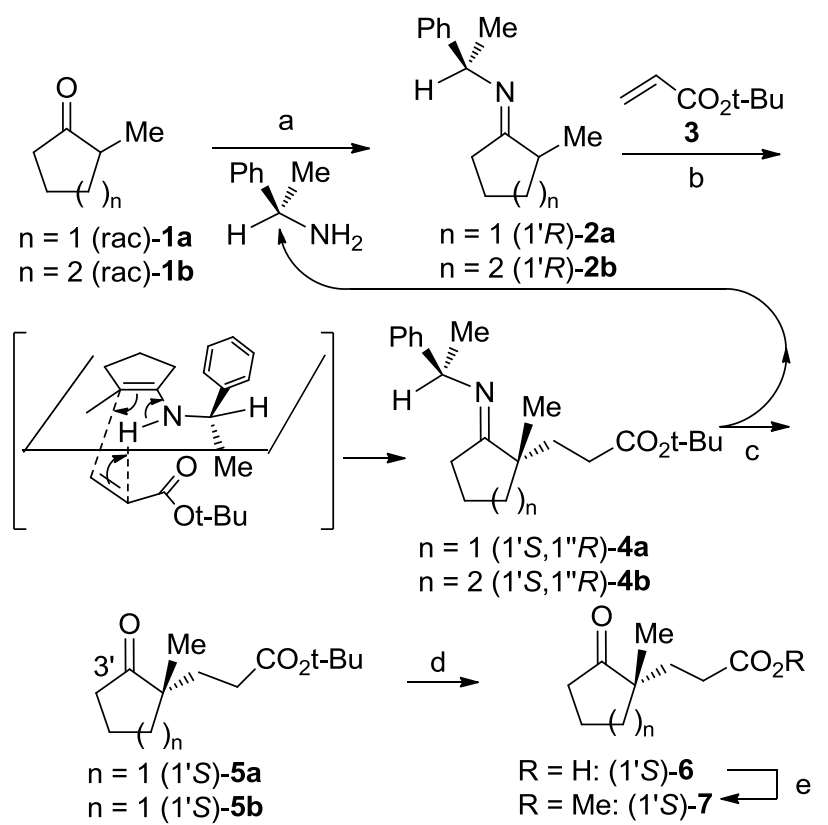

Scheme 1 Reagents and conditions: (a) $1.01 \mathrm{eq}$ 1-phenylethylamine, cyclohexane, reflux, DeanStark, overnight, $89 \%$ (b) 2 equiv. 2, $25-200{ }^{\circ} \mathrm{C}$ (see Tables 1 and 2); (c) $20 \%$ aq. $\mathrm{AcOH}$, THF,
$20{ }^{\circ} \mathrm{C}$ (d) $\mathrm{HCO}_{2} \mathrm{H}, 20{ }^{\circ} \mathrm{C}, 89 \%$; (e) $\mathrm{CH}_{2} \mathrm{~N}_{2}, \mathrm{Et}_{2} \mathrm{O}$, 0 to $20^{\circ} \mathrm{C}, 2 \mathrm{~h}, 95 \%$.

When the reaction was performed at $100{ }^{\circ} \mathrm{C}$ for $4 \mathrm{~h}$, alkylated imine $\mathbf{4} \mathrm{a}^{11}$ was obtained as the sole product leading upon hydrolysis to keto ester 5 in $79 \%$ yield. On the basis of its ${ }^{13} \mathrm{C}$ NMR spectrum, crude imine $\mathbf{4 a}$ exists as a single stereoisomer (de $>95 \%),{ }^{11}$ as the result of a highly stereo-controlled process, giving rise to Michael adduct 5a with a $>95 \%$ enantiomeric excess (ee). The reaction duration was markedly reduced to $30 \mathrm{~min}$ at $150{ }^{\circ} \mathrm{C}$ and ketoester $\mathbf{5}$ was obtained in an optimum 92\% yield upon hydrolysis. However, the stereoselectivity proved to be lower (ee 80\%) than at $100{ }^{\circ} \mathrm{C}$ (Table 1, entry 6). Finally, both the efficiency and the stereoselectivity dropped at $200{ }^{\circ} \mathrm{C}$ (Table 1, entry 7).

Table 1. Effect of temperature on the synthesis of ketoester 4 by condensation of chiral imine $\mathbf{1}$ with tert-butyl acrylate $2 .^{\text {a }}$

\begin{tabular}{cclcl}
\hline Entry & $\begin{array}{c}\text { Temperature } \\
\left({ }^{\circ} \mathrm{C}\right)\end{array}$ & Time & $\begin{array}{c}\mathbf{5} \\
\text { yield } \%{ }^{\mathrm{b}}\end{array}$ & $\begin{array}{l}\mathbf{5} \\
\mathrm{ee} \%\end{array}$ \\
\hline 1 & 25 & $7 \mathrm{~d}$ & 15 & $\mathrm{nd}^{\mathrm{c}}$ \\
2 & 60 & $1 \mathrm{~d}$ & 58 & $>95$ \\
$3^{\mathrm{b}}$ & 100 & $4 \mathrm{~h}$ & 79 & $>95$ \\
4 & 150 & $5 \mathrm{~min}$ & 14 & $\mathrm{nd}^{\mathrm{c}}$ \\
5 & 150 & $15 \mathrm{~min}$ & 59 & $\mathrm{nd}^{\mathrm{c}}$ \\
6 & 150 & $30 \mathrm{~min}$ & 92 & 80 \\
7 & 200 & $30 \mathrm{~min}$ & 57 & 80 \\
\hline
\end{tabular}

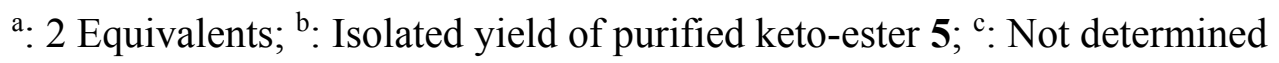

d: Determined by ${ }^{13} \mathrm{C}-\left\{{ }^{1} \mathrm{H}\right\}$ NMR in chiral liquid crystals.

Concerning the stereoselectivity of the process, attempts to measure accurately the ee in adduct $5 \mathbf{a}$ or in the related keto-acid $\mathbf{6}$ using either chiral HPLC or ${ }^{1} \mathrm{H}$ NMR spectroscopy in the presence of chiral shift reagent $\left[\mathrm{Eu}(\mathrm{hfc})_{3}\right]$ were unsuccessful. However, screening of the selectivity was made possible on the examination of ${ }^{13}$ CNMR spectra of crude imine $\mathbf{4 a}$ and gave satisfactory results. In order to ascertain that no epimerization of Michael adduct 5a occurred 
during hydrolysis of imine 4a, we turned our attention to NMR spectroscopy in polypeptide chiral liquid crystals (CLC) that generally provides an efficient alternative to classical methods when these latter failed or gave poor results. ${ }^{12}$ We used here ${ }^{13} \mathrm{C}-\left\{{ }^{1} \mathrm{H}\right\} .{ }^{13}$ Spectral enantio-discriminations using ${ }^{13} \mathrm{C}-\left\{{ }^{1} \mathrm{H}\right\}$ NMR in a CLC are based on ${ }^{13} \mathrm{C}$ chemical shift anisotropy (CSA) differences. In practice, when the enantiomers are oriented differently inside the CLC, we can expect to observe two distinct resonances for each non-equivalent carbon atom discriminated. A priori, each carbon atom is a potential spy, thus increasing the possibility to visualize enantiomers. ${ }^{14}$ Various carbon sites show enantiodiscrimination, but the best spectral separation was obtained for C3' in compound 5 . Considering the $\mathrm{S} / \mathrm{N}$ ratio, the error on the ee has been estimated around 5\% of the true value. Figure 1 shows the evolution of two ${ }^{13} \mathrm{C}-\left\{{ }^{1} \mathrm{H}\right\}$ signals associated to C-3' (Scheme 2) both in racemic (a) and enantio-enriched forms [Table 1, entry 6 (b) and Table 2, entry 4 (c)] oriented in a PBLG/ dichloromethane phase. The differences in peak intensity reveal the evolution of the ee. Although the separation observed at $100 \mathrm{MHz}$ is rather small $(<3 \mathrm{~Hz})$, a suitable evaluation of the ee is possible using deconvolution process. The absence of peak for the minor enantiomer in Fig. $1 \mathrm{c}$ indicates that the ee is $>95 \%$. Accuracy of the method was ascertained by measuring gradual mixtures of the racemic ketoester 5a (prepared from racemic 1-phenymethymamine using the same conditions) with the pure enantiomer.
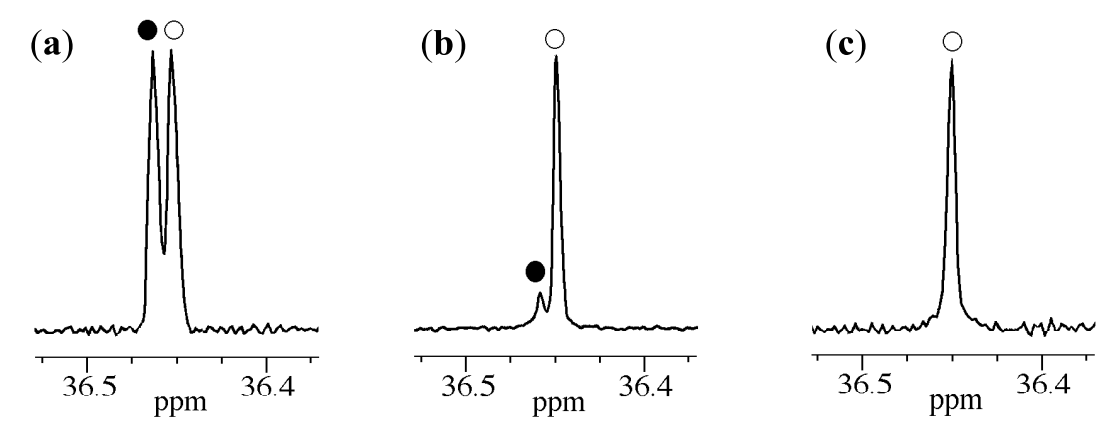

Figure 1. ${ }^{13} \mathrm{C}-\left\{{ }^{1} \mathrm{H}\right\}$ signals of carbon atom $\mathrm{C}-3$ ' in ketoester 5 prepared in racemic form $(\mathbf{a})$ and $(S)$ enriched one (b, c).

Analysis of NMR results obtained for synthesis of adduct 5a using $\Delta$ clearly indicates a sharp decrease in the stereoselectivity ( $>95$ to $80 \%$ ee) when the temperature was increased from $100{ }^{\circ} \mathrm{C}$ to $200{ }^{\circ} \mathrm{C}$ (Table 1 , entries 3-4 and 6-7). This phenomenon can tentatively be explained assuming a possible competitive retro-Michael addition leading to a partial racemization of the Michael adduct under rather drastic conditions. ${ }^{15}$
Having secured an access to Michael adduct 5a, a chemical correlation of its corresponding methyl keto ester $6^{10}$ was undertaken to ascertain the absolute configuration in 5a (Scheme 1). Thus, keto acid 6 was easily obtained upon formic acid treatment of ketoester 5a (Table 1, entry 3$)$ in good yield and directly subjected to diazomethane esterification leading to (-)-(S)-7. As expected, the sense of induction is in 
accordance to the empirical rule defined for this reaction, ${ }^{2,3}$ with the same sense of asymmetric induction as those obtained using methyl acrylate as the electrophile. This stereoselectivity originates from the aza-ene type mechanism in which internal transfer of the proton born by the nitrogen atom of the more substituted tautomeric enamine is concerted with the creation of the $\mathrm{C}$ $\mathrm{C}$ bond (Scheme 1).

We then turned our focus to the study of this Michael reaction, carrying out the experiments under $\mu \mathrm{W}$. As can be seen from Table 2 and Scheme 3, $\mu \mathrm{W}$ affects the reactivity, the stereoand unexpectedly the chemoselectivity (Table 2). The closed vessel system was chosen in order to contain the toxic and volatile Michael acceptors in the reaction vessel, and to monitor the possible extent of pressure elevation during the microwave irradiation. The possibility of running reactions in an inert gas atmosphere is another distinct advantage with the sealed reaction vessel strategy. Despite sensitivity of chiral imines 2 toward water, this was not necessary in this case. The first observation was the role of stirring upon efficiency of the reaction. This parameter was found to be critical to the success of the reaction (compare entries 1,3,5 with entries 2,4,6 and 7). ${ }^{16}$

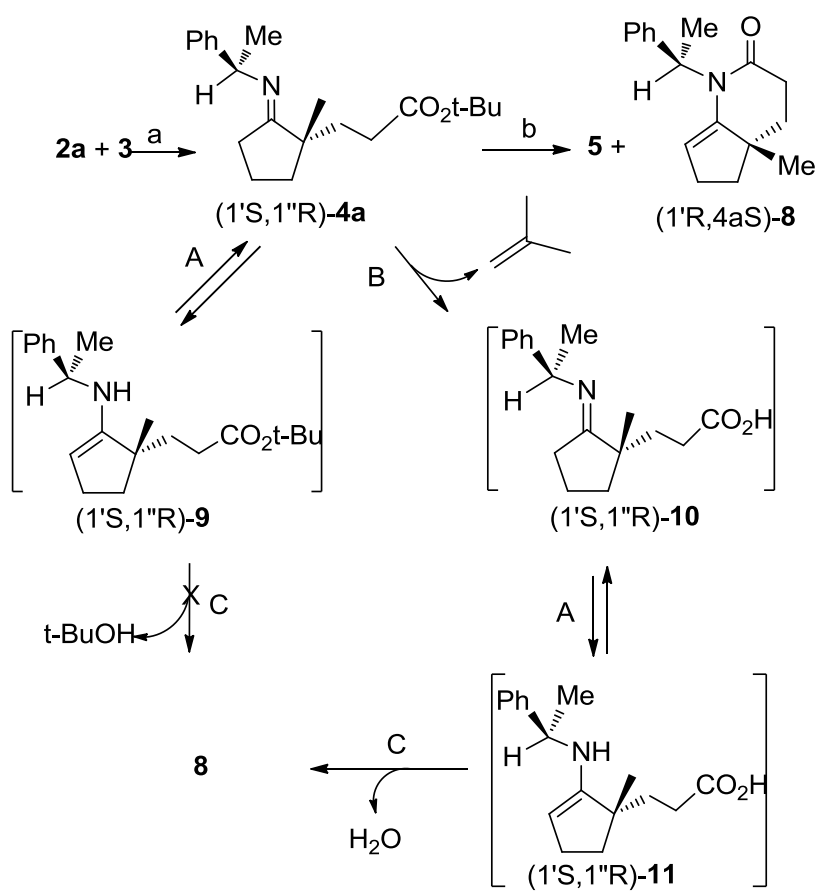

Scheme 2 Reaction pathway to lactam 8 under $\mu \mathrm{W}$. Reagents and conditions: (a) 2 equiv. 3, $\mu \mathrm{W}, 200{ }^{\circ} \mathrm{C}, 30 \mathrm{~min}$; (b) $20 \%$ aq. $\mathrm{AcOH}, \mathrm{THF}$, $20{ }^{\circ} \mathrm{C}$.

When mixtures of imine $\mathbf{2 a}$ and alkene $\mathbf{3}$ were submitted to $\mu \mathrm{W}$ for $30 \mathrm{~min}$ at $100{ }^{\circ} \mathrm{C}$ with an optimal power of $30 \mathrm{~W}$ (Table 2, entry 2), the only reaction product was the expected chiral imine 4a, leading to keto-ester 5a upon hydrolytic workup. This result is a noteworthy improvement over results obtained from conventional heating at the same temperature for 4 hours (Table 1 , entry 3 ) in terms of yields and reaction time, the enantioselectivity remaining the same.

At $150{ }^{\circ} \mathrm{C}$, within $30 \mathrm{~min}$, whereas yields were nearly comparable (Table 1, entry 6 and Table 2, entry 4), the enantioselectivity was largely improved under $\mu \mathrm{W}$ when compared to $\Delta$ (see Figure 1) with similar set of conditions (temperature, pressure, profiles of heating rates).

Table 2. Effect of $\mu \mathrm{W}$ irradiation and stirring upon condensation of imine 2a (entries 1-7) and 2b (entries 8-9) to tert-butyl acrylate $\mathbf{3}^{\mathrm{a}}$. 


\begin{tabular}{ccccccc}
\hline Entry & $\mathrm{P}$ & $\mathrm{T}\left({ }^{\circ} \mathrm{C}\right)$ & Stirring & $\begin{array}{c}\Delta \mathrm{P} \\
(\mathrm{bar})\end{array}$ & $\begin{array}{c}\mathbf{5 a} / \mathbf{5 b} \\
\text { yield }(\mathrm{ee}) \%\end{array}$ & $\mathbf{8}$ \\
\hline 1 & 30 & 100 & no & 0.1 & 85 & 0 \\
2 & 30 & 100 & yes & 0.1 & $100\left(>95^{\mathrm{d}}\right)$ & 0 \\
3 & 80 & 150 & no & 0.7 & 67 & 0 \\
4 & 80 & 150 & yes & 0.3 & $89\left(>95^{\mathrm{d}}\right)$ & 0 \\
5 & 80 & 200 & no & 3.5 & 11 & 25 \\
6 & 80 & 200 & yes & 1.4 & 41 & 14 \\
7 & 100 & 200 & yes & 13.0 & 0 & 53 \\
8 & 80 & 100 & yes & 0.8 & $92\left(>95^{\mathrm{d}}\right)$ & 0 \\
9 & 100 & 200 & yes & 14.0 & 0 & 68 \\
\hline
\end{tabular}

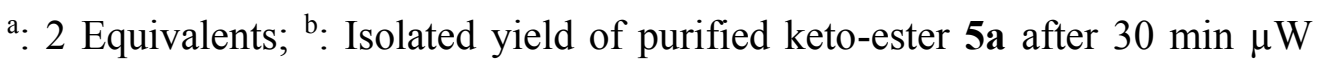
irradiation and subsequent hydrolysis; ${ }^{c}$ : Not determined; ${ }^{d}$ : Determined by ${ }^{13} \mathrm{C}-\left\{{ }^{1} \mathrm{H}\right\}$ NMR in chiral liquid crystals.

The most intriguing feature concerned the production of lactam 8 under forcing $\mu \mathrm{W}$ conditions (Scheme 3; Table 2, entries 5-7) instead of keto ester $\mathbf{5 a}$, since this lactam $\mathbf{8}$ was never observed in the conventional thermal process $(\Delta)$. This very important specific $\mu \mathrm{W}$ effect appeared when the reaction was performed at $200{ }^{\circ} \mathrm{C}$. In contrast with $\Delta$ where the expected Michael adduct 5a was obtained (Table 1, entry 7), within $30 \mathrm{~min}$ under $\mu \mathrm{W}$ irradiation at $200^{\circ} \mathrm{C}$, quite surprisingly, the lactam $\mathbf{8}$ was formed as the sole product (Scheme 2; Table 2, entry 7).

This noticeable finding on chemoselectivity can be justified by considering the possibility for $\mu \mathrm{W}$ to favor a very polar mechanism consisting in the nucleophilic addition (Scheme 2, routes $\mathrm{C}$ ) of the enamines $\mathbf{9}$ or $\mathbf{1 1}$ to the carbonyl group of either a tert-butyl ester $(\mathbf{9} \rightarrow \mathbf{8})$ with the release of tert-butanol, or an acid $(\mathbf{1 1} \rightarrow \mathbf{8})$ with elimination of a water molecule. Secondary enamines $\mathbf{9}$ or $\mathbf{1 1}$ are in tautomeric equilibrium (Scheme 2, routes A) with imines $4 a$ or $\mathbf{1 0}$ respectively, the latter being issued from the thermolysis of the tert-butyl ester group in imine
4 with concomitant generation of isobutene (Scheme 2, route B, $\mathbf{4} \rightarrow \mathbf{1 0}$ ).

In order to elucidate the pathway to lactam $\mathbf{8}$, a GC-mass analysis of the headspace of the reaction mixture was undertaken, and compared to those of the starting chiral imine 2 , the acrylate $\mathbf{3}$ and tert-butanol having been separately irradiated under the same conditions $\left(200{ }^{\circ} \mathrm{C}, 100 \mathrm{~W}, 30 \mathrm{~min}\right.$ in closed reaction vessels). While isobutene was detected in the headspace of the reaction mixture and the tertbutyl acrylate 3 sample, it was not present in the tert-butanol or starting imine $\mathbf{1}$ ones. ${ }^{17}$ This indicates that, under $\mu \mathrm{W}$ at $200{ }^{\circ} \mathrm{C}$, the formation of lactam 8 occurred via a tandem Michael addition/deprotection/aza-annulation sequence implying the thermolysis of the tert-butyl ester group in imine 4 (path $\mathrm{B} / \mathrm{C}$ ).

Dealing with $\mu \mathrm{W}$ effect on enantioselectivity, the superiority of $\mu \mathrm{W}$ reveals the intervention of non-purely thermal $\mu \mathrm{W}$ specific effects. Although the effects observed in microwaveirradiated chemical transformations can in most cases be rationalized by purely bulk thermal 
phenomena associated with rapid heating to elevated temperatures, ${ }^{18}$ we have conducted all experiments in the same conditions (closed vessels, same scale, same magnetic barrel) either in the microwave chamber or by immersion in a preheated oil bath in order to avoid as possible any difference in the temperature profiles. They can be justified by considering the reaction mechanism, ${ }^{4}$ expecting $\mu \mathrm{W}$ effects when the polarity of the system increases during the reaction progress. It will be the case when the transition state (TS) of a reaction is more polar than its ground state, thus leading to a decrease in the activation energy. ${ }^{19}$ Data obtained for the transition states for the $\mathrm{Re}$ and $\mathrm{Si}$-approaches of imine $\mathbf{2}$ and tert-butyl acrylate $\mathbf{3}$ are consistent with the previous studies: ${ }^{4 \mathrm{~b}}$ Re approach: forming CC bond: $1.87 \AA$ and forming $\mathrm{CH}$ bond: $2.56 \AA$; Si approach: forming CC bond: $1.89 \AA$ and forming $\mathrm{CH}$ bond: $2.50 \AA$ (Figure 2). As it was shown that this Michael addition proceeds through a concerted asynchronous 'aza-ene like' mechanism, ${ }^{4}$ the TS has thus a certain polarity, a situation for which $\mu \mathrm{W}$ effects are expected. This fact explains the intervention of $\mu \mathrm{W}$ effects upon exaltation of reactivity (comparing yields at $100{ }^{\circ} \mathrm{C}$ ). To support this assumption, taking into account previous related AM1 computational investigations, ${ }^{20}$ we calculate the corresponding approaches between the enamine tautomer of imine 2 with tert-butyl acrylate 3 . The $R e$ approach (the favored one) leads to a slightly more polar as well as more asynchronous than the Si-approach TS (Figure 2). ${ }^{21}$ Consequently, this TS will be slightly favored due to a better dipole-dipole stabilization by $\mu \mathrm{W}$. Therefore, under $\mu \mathrm{W}$, the selectivity in favor of the $R e$ approach will be even more improved (exp. from 80 to $>95 \%$ ee). Reduced reversibility of the Michael reaction under microwave conditions could also contribute to the superior enantioselectivity, both phenomenon leading to an increased stereoselectivity in such conditions.

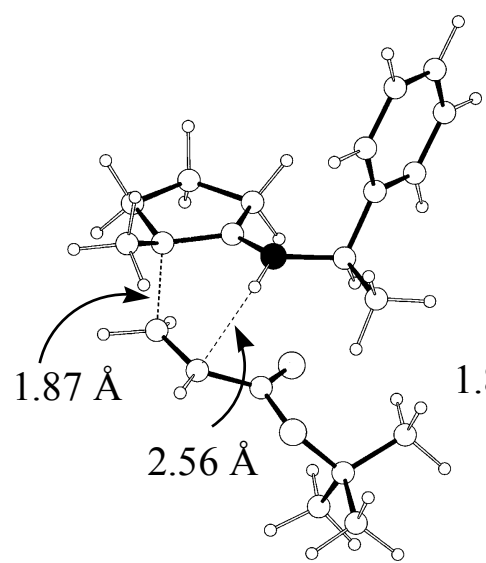

Re approach

$\Delta \mathrm{H}=-37.22 \mathrm{kcal} / \mathrm{mol}$

$\mu=4.37 \mathrm{D}$

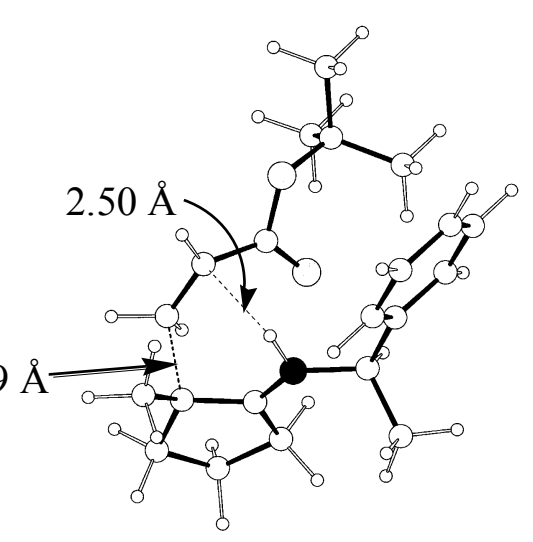

Si approach

$\Delta \mathrm{H}=-34.12 \mathrm{kcal} / \mathrm{mol}$ $\mu=4.33 \mathrm{D}$

Figure 2. Transition structures at the RHF AM1 level for Re (left) and Si (right) approaches of tertbutyl acrylate 3 to enamine imine 2 , their respective enthalpies of formation and dipole moment. ${ }^{20}$ 
The same trend was observed with chiral imine $\mathbf{2 b}$ derived from 2-methylcyclohexanone 1b. Lactame 8b was obtained when the reaction was performed at $200{ }^{\circ} \mathrm{C}$ upon irradiation at 100 $\mathrm{W}$ for $30 \mathrm{~min}$ (Table 2, entry 9 ) in a $68 \%$ yield while the expected Michael adduct $5 b$ was obtained in the optimized conditions $\left(100{ }^{\circ} \mathrm{C}, 80\right.$ $\mathrm{W}$, Table 2, entry 8 ) in $92 \%$ yield with $>95 \%$ ee. We next examine the reactivity of these imine in this $\mu \mathrm{W}$ promoted AMACI (Table 3 ).

Table 3. Effect of temperature on the synthesis of ketoester 4 by condensation of chiral imine 1 with electrophilic alkenes 12a-d. ${ }^{\mathrm{a}}$

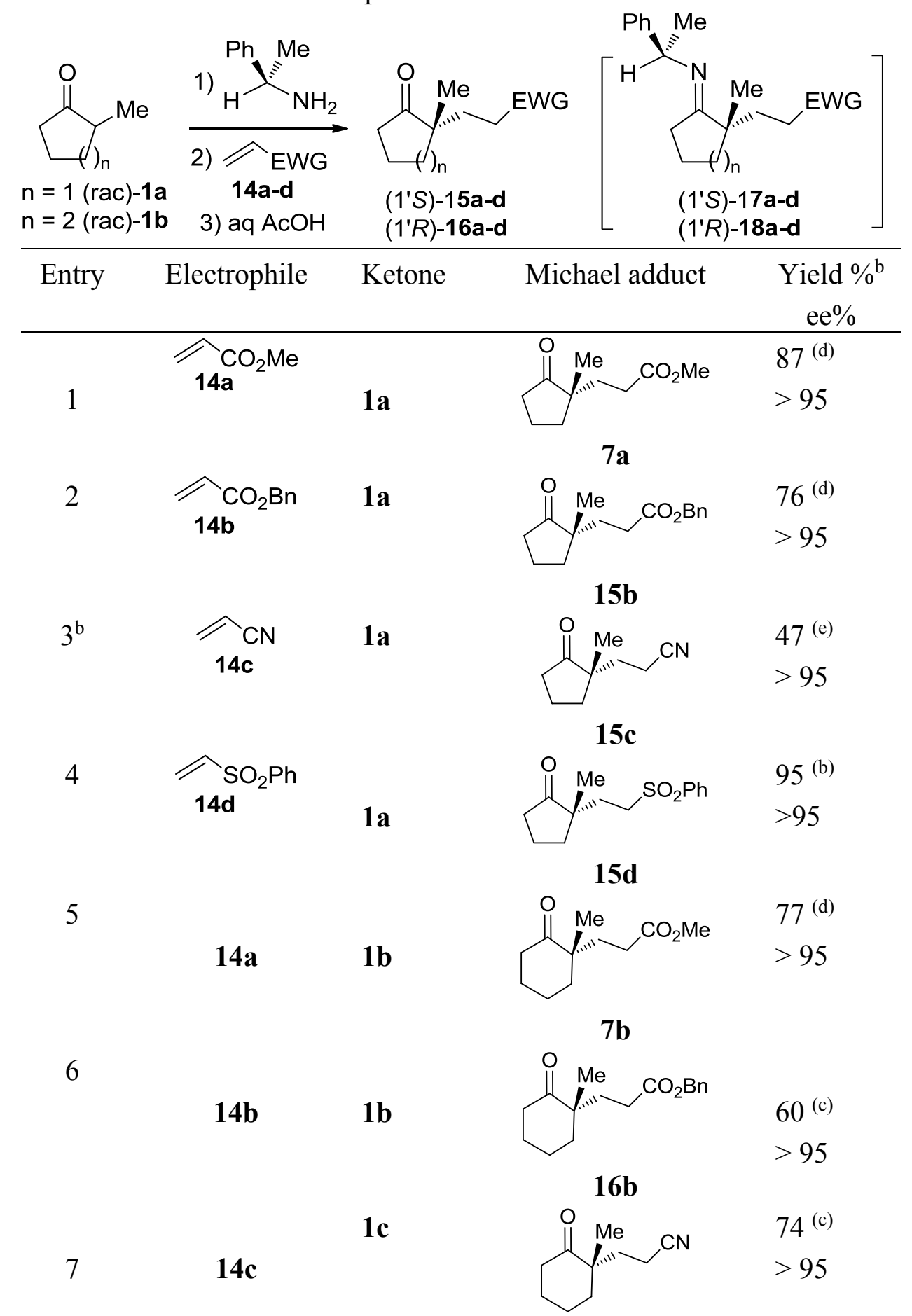


$16 \mathrm{c}$

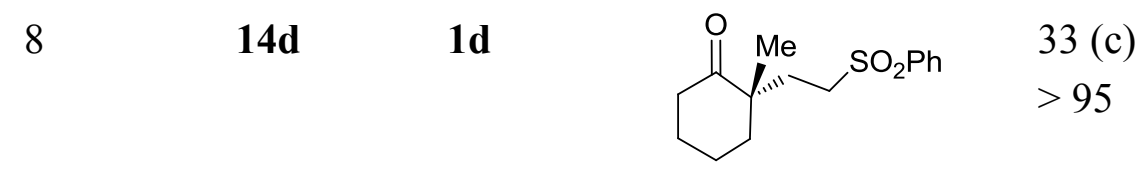

16d

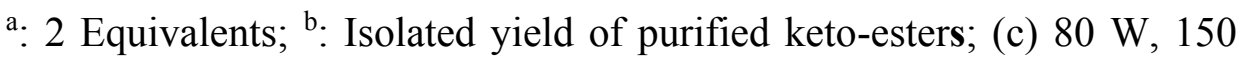

${ }^{\circ} \mathrm{C}, 30 \mathrm{~min}$.; (d) $80 \mathrm{~W}, 100{ }^{\circ} \mathrm{C}, 30 \mathrm{~min}$.; (e) $80 \mathrm{~W}, 100{ }^{\circ} \mathrm{C}, 15 \mathrm{~min}$.

The reaction performed well, giving the expected Michael adducts in adduct in $33-95 \%$ yield, in a first series of experiments. Ee of the adducts were measured at the level of the crude imines as $>95 \%$ (no diastereoisomers detected).

With these satisfactory results in hand, we will turn to the study of a catalytic version of this

\section{Materials and Methods}

3a. Chemistry: General: All reactions not involving aqueous media were carried out under a nitrogen atmosphere in a flame-dried glassware. Commercial reagents were used without further purification. Reactions were followed by ${ }^{1} \mathrm{H}$ NMR in $\mathrm{CDCl}_{3}$ or using thinlayer chromatography, carried out on silica gel plates, which were viewed by UV irradiation at $254 \mathrm{~nm}$ and/or by staining with phosphomolybdic acid or $p$-anisaldehyde. Flash column chromatography was performed with 230-400 mesh silica gel. Melting points were recorded on a digital melting point apparatus. IR spectra were recorded with a Fourier transform spectrometer Bruker VECTOR 22. NMR spectra of the crude reaction mixtures were recorded in $\mathrm{CDCl}_{3}$ containing a pinch of sodium carbonate in order to prevent hydrolysis of the imines. Imines proved to be stable for days in such conditions. ${ }^{1} \mathrm{H}$ NMR spectra were recorded at $300 \mathrm{~K}$, at 200 or $400 \mathrm{MHz}$ on a Bruker $\mathrm{AC} 200$ or Bruker Avance 400 spectrometer, with $\mathrm{CHCl}_{3}$ as internal reaction, in the context of a greener generation of quaternary carbon centers in a simple manner. Work is in progress to extend this $\mu \mathrm{W}$ activation mode to engage substituted acceptors in the AMACI.

standard $\left(\delta_{\mathrm{H}}=7.26 \mathrm{ppm}\right) .{ }^{13} \mathrm{C}$ NMR spectra were recorded at $300 \mathrm{~K}$, at 50 or $100 \mathrm{MHz}$, with the central peak of $\mathrm{CHCl}_{3}$ as internal standard $\left(\delta_{\mathrm{C}}=\right.$ 77.0 ppm, central line). Recognition of methyl, methylene, methine and quaternary carbon nuclei in ${ }^{13} \mathrm{C}$ NMR spectra rests on the $J$-modulated spin-echo sequence. 2Dl NMR experiments (COSY, HMQC, HMBC and NOESY) were used for the assignments of signals in the ${ }^{1} \mathrm{H}$ and ${ }^{13} \mathrm{C}$ NMR spectra. For NMR measurements, ${ }^{13} \mathrm{C} 1 \mathrm{D}$ NMR experiments in polypeptidic oriented solvents were performed on a Bruker DRX-400 equipped with a $\mathrm{BBO}$ probe, and hence no additional hardware equipment is basically required. All proton-decoupled ${ }^{13} \mathrm{C}$ NMR experiments were recorded by applying the WALTZ-16 composite pulse sequence to decouple protons and benefit from NOE effect. For unambiguous assignment of enantiomers in chiral NMR, comparison was made in all cases with the corresponding racemates. Optical rotations were measured at $589 \mathrm{~nm}$ in a $1 \mathrm{dm}$-cell 
using an Optical Activity Limited AA-10R apparatus and are expressed in $\mathrm{g} / 100 \mathrm{~mL}$. Elemental analyses were performed by the Service de microanalyse, BioCIS, ChâtenayMalabry, France, with a Perkin-Elmer 2400 analyzer. A CEM Discover monomode reactor with an accurate control of temperature and pressure by modulation of emitted W was used for the microwave experiments. Caution: It is essential that great precaution be taken when carrying out organic reactions in sealed vessels. In particular, safety devices are to be used including appropriate septa as a pressure relief system and an automatic cut off of the microwave irradiation before the pressure limit of the vessels has been reached. See: Raner, K. D.; Strauss, C. R.; Trainor, R. W.; Thorn, S. J. J. Org. Chem. 1995, 60, 2456 and references cited therein. In this study, the maximum developed pressure was 14 bar at $100 \mathrm{~W}$ and $200{ }^{\circ} \mathrm{C}$, far below the pressure limit (20 bar).

Preparation of chiral imines $\mathbf{2}$ exemplified for 2a: In a $100 \mathrm{~mL}$ round bottom flask equipped with a Dean-Stark apparatus, $21.6 \mathrm{~mL}(0.2 \mathrm{~mol})$ 2-methylcyclopentanone, $27.3 \mathrm{~mL}(0.21 \mathrm{~mol}$, 1.05 equiv.) $(R)$-1-phenylethylamine (ee $=99 \%)$ are successively added to cyclohexane $(50 \mathrm{~mL})$. The resulting mixture was stirred for $18 \mathrm{~h}$ under nitrogen at $110{ }^{\circ} \mathrm{C}$ (oil bath) with azeotropic removal of water. Cyclohexane was then distilled and fractional distillation of the crude under reduced pressure afforded the desired chiral imine $\mathbf{1}$ as a colourless oil.

\section{(1'R)-(2-Methylcyclopentylidene)-(1'-phenyl-} ethyl)-amine (2a). Colorless oil (89\%); B.p. = $80{ }^{\circ} \mathrm{C}$ (0.01 Torr); IR (neat, $v \mathrm{~cm}^{-1}$ ): 2958, 1673; ${ }^{1} \mathrm{H}$ NMR $\left(200 \mathrm{MHz}, \mathrm{CDCl}_{3}\right) \delta \mathrm{ppm}: 7.33-7.05$ (m, 5H), 4.43-4.28 (m, 1H), 2.45-1.15 (m, 7H), 1.43 and $1.41(\mathrm{~d}, J=6.1 \mathrm{~Hz}, 3 \mathrm{H}), 1.11$ and 1.10 $(\mathrm{d}, J=6.7 \mathrm{~Hz}, 3 \mathrm{H}) ;{ }^{13} \mathrm{C} \mathrm{NMR}\left(50 \mathrm{MHz}, \mathrm{CDCl}_{3}\right)$ $\delta$ ppm: 181.0 and $180.6(\mathrm{C}), 146.2$ and $145.9(\mathrm{C})$, $128.1(2 \mathrm{CH}), 126.5(\mathrm{CH}), 126.3(2 \mathrm{CH}), 61.5$ and $61.2(\mathrm{CH}), 41.2$ and $41.1(\mathrm{CH}), 32.8$ and 32.7 $\left(\mathrm{CH}_{2}\right), 28.7$ and $28.5\left(\mathrm{CH}_{2}\right), 24.8$ and $24.5\left(\mathrm{CH}_{3}\right)$, 22.5 and $22.4\left(\mathrm{CH}_{2}\right), 17.5\left(\mathrm{CH}_{3}\right)$.

General procedure for the asymmetric Michael reactions using microwaves: Mixtures of imines 2 ( 1 to $6 \mathrm{mmol}$ ) and 2 equivalents of electrophilic alkene were placed in sealed, ${ }^{33} 10$ mL heavy-walled pyrex tubes. ${ }^{34}$ The tubes were introduced in the cavity of a single-mode ${ }^{35}$ device allowing control of irradiation power (up to $300 \mathrm{~W}$ ), time, temperature and pressure (see article, Tables 1 and 2). ${ }^{36}$ The tube was opened after the reaction mixture was rapidly cooled down to room temperature, and excess tert-butyl acrylate was removed in vacuo. An aliquot of crude reaction mixture was analyzed by ${ }^{1} \mathrm{H}$ and ${ }^{13} \mathrm{C}$ NMR. For the crude reaction mixtures containing alkylated imine, after being vigorously stirred with $20 \%$ aqueous acetic acid (2 $\mathrm{mL} / \mathrm{mmol})$ and THF $(2 \mathrm{~mL} / \mathrm{mmol})$ for 17 hours, the reaction mixture was concentrated, then thoroughly extracted with $\mathrm{Et}_{2} \mathrm{O}(3 \times 10 \mathrm{~mL})$. The combined organic phase was washed successively with saturated $\mathrm{NaHCO}_{3}$ and $\mathrm{NaCl}$ solutions, dried $\left(\mathrm{MgSO}_{4}\right)$, filtered over Celite ${ }^{\circledR}$ and concentrated in vacuo. Chromatographic purification on silica gel (cyclohexane:ethyl acetate, 9:1) afforded keto derivatives 5 and/or lactam 8 as colorless oils.

tert-Butyl (1'S,1'R)-3-[1'-Methyl-2-(1'phenyl-ethyl-imino)-cyclopentyl]-propionate

4a. IR (neat, $v \mathrm{~cm}^{-1}$ ): 2966, 2868, 1726, $1673 ;{ }^{1} \mathrm{H}$ NMR $\left(200 \mathrm{MHz}, \mathrm{CDCl}_{3}\right) \delta$ ppm: 7.38-7.07 (m, $5 \mathrm{H}), 4.35$ (q, $1 \mathrm{H}, J=6.6 \mathrm{~Hz}), 2.37-2.04(\mathrm{~m}, 4 \mathrm{H})$, 1.86-1.41 (m, 6H), 1.38 (s, 9H), $1.36(\mathrm{~d}, 3 \mathrm{H}, J=$ $6.6 \mathrm{~Hz}), 0.98(\mathrm{~s}, 3 \mathrm{H}) ;{ }^{13} \mathrm{C} \mathrm{NMR}\left(50 \mathrm{MHz}, \mathrm{CDCl}_{3}\right)$ $\delta$ ppm: 180.7 (C), 173.5 (C), 146.2 (C), 128.0 $(2 \mathrm{CH}), 126.3(2 \mathrm{CH}), 126.1(\mathrm{CH}), 79.7(\mathrm{C}), 60.8$ $(\mathrm{CH}), 45.5(\mathrm{C}), 37.0\left(\mathrm{CH}_{2}\right), 33.4\left(\mathrm{CH}_{2}\right), 30.9$ 
$\left(\mathrm{CH}_{2}\right), 28.4\left(\mathrm{CH}_{2}\right), 28.0\left(3 \mathrm{CH}_{3}\right), 24.8\left(\mathrm{CH}_{3}\right)$, $23.9\left(\mathrm{CH}_{3}\right), 20.5\left(\mathrm{CH}_{2}\right)$.

\section{tert-Butyl (1'S,1'R)-3-[1'-Methyl-2-(1"-} phenyl-ethyl-imino)-cyclohexyl]-propionate

4b. IR (neat, $v \mathrm{~cm}^{-1}$ ): 3061, 3063, 2966, 2926, 1658, 1493, 1447; ${ }^{1} \mathrm{H}$ NMR $\left(300 \mathrm{MHz}, \mathrm{CDCl}_{3}\right)$ $\delta$ ppm: 7.41-7.12 (m, 5H), 4.69 (q, 3H, $J=6.4$ $\mathrm{Hz}), 2.40-2.21(\mathrm{~m}, 1 \mathrm{H}), 1.57-1.30(\mathrm{~m}, 8 \mathrm{H}), 1.17-$ $1.11(2 \mathrm{~d}, 3 \mathrm{H}, J=4.3 \mathrm{~Hz}), 1.01-0.99$ (d, 3H, $J=$ $4,9 \mathrm{~Hz}) ; \mathrm{RMN}{ }^{13} \mathrm{C}\left(75 \mathrm{MHz}, \mathrm{CDCl}_{3}\right) \delta \mathrm{ppm}$ : $173.1(\mathrm{C}), 146.7(\mathrm{C}), 127.9(\mathrm{CH}), 126.3(\mathrm{CH})$, $126.2(\mathrm{CH}), 125.9(\mathrm{CH}), 125.8(\mathrm{CH}), 57.3(\mathrm{CH})$, $42.0\left(\mathrm{CH}_{2}\right), 35.6(\mathrm{CH}), 27.5\left(\mathrm{CH}_{2}\right), 25.4\left(\mathrm{CH}_{3}\right)$, $25.3\left(\mathrm{CH}_{2}\right)$.

\section{tert-Butyl (1'S)-3-(1'-Methyl-2'-oxocyclo-} pentyl)-propionate 5a. IR (neat, $v \mathrm{~cm}^{-1}$ ): 2968, 2934, 2872, 1727; ${ }^{1} \mathrm{H}$ NMR (200 MHz, $\left.\mathrm{CDCl}_{3}\right) \delta$ ppm: 2.38-2.06 (m, 4H), 2.0-1.54 (m, 6H), 1.36 (s, 9H), 0.98 (s, 3H); $\left.{ }^{13} \mathrm{C} \mathrm{NMR} \mathrm{(50} \mathrm{MHz,} \mathrm{CDCl}_{3}\right)$ $\delta$ ppm: 222.3 (C), 172.6 (C), 80.1 (C), 47.4 (C), $37.3\left(\mathrm{CH}_{2}\right), 35.9\left(\mathrm{CH}_{2}\right), 31.3\left(\mathrm{CH}_{2}\right), 30.5\left(\mathrm{CH}_{2}\right)$, $27.9\left(3 \mathrm{CH}_{3}\right), 21.3\left(\mathrm{CH}_{3}\right), 18.4\left(\mathrm{CH}_{2}\right) ;[\alpha]_{\mathrm{D}}{ }^{24}=$ $27.8\left(\mathrm{c}=4.5, \mathrm{EtOH}_{\mathrm{abs}}\right)$; Anal. calcd for $\mathrm{C}_{13} \mathrm{H}_{22} \mathrm{~N}$ : C, 68.99; H, 9.80. Found: C, 68.84; H, 9.75\%.

\section{tert-Butyl (1'S)-3-(1'-Methyl-2'-oxocyclo-} hexyl)-propionate $5 \mathbf{b}$. IR (neat, $v \mathrm{~cm}^{-1}$ ): 29332866, 1727, 1704; RMN ${ }^{1} \mathrm{H}\left(200 \mathrm{MHz}, \mathrm{CDCl}_{3}\right) \delta$ ppm: 2.49-2.33 (2H), 2.28-2.12 (1H), 2.10-1.94 (3H), 1.92-1.52 (8H), $1.42(9 \mathrm{H}), 1,02(3 \mathrm{H})$; $\mathrm{RMN}{ }^{13} \mathrm{C}\left(75 \mathrm{MHz}, \mathrm{CDCl}_{3}\right): \delta$ ppm: $215.7(\mathrm{C})$, 173.1 (C), $82.3(\mathrm{C}), 47.9(\mathrm{C}), 39.3\left(\mathrm{CH}_{2}\right), 38.7$ $\left(\mathrm{CH}_{2}\right), 32.4\left(\mathrm{CH}_{2}\right), 30.3\left(\mathrm{CH}_{2}\right), 28.7\left(3 \mathrm{CH}_{2}\right), 27.4$ $\left(\mathrm{CH}_{2}\right), 22.4\left(\mathrm{CH}_{3}\right), 21.0\left(\mathrm{CH}_{2}\right)$.

\section{(4aS,1'R)-4a-Methyl-1-(1'-phenylethyl)-} 1,3,4,4a，5,6-hexahydro-[1]pyrindin-2-one 8 . IR (neat, $\left.v \mathrm{~cm}^{-1}\right): 1665,1629 ;{ }^{1} \mathrm{H} \mathrm{NMR}\left(\mathrm{CDCl}_{3}\right.$, $200 \mathrm{MHz}) \delta \mathrm{ppm}:$ 7.24-7.06 (m, 5H), 6.14 (q, $1 \mathrm{H}, J=7.1 \mathrm{~Hz}), 4.31(\mathrm{t}, 1 \mathrm{H}, J=2.5 \mathrm{~Hz}), 2.62-$ $2.53(\mathrm{~m}, 1 \mathrm{H}), 2.57(\mathrm{dd}, 1 \mathrm{H}, J=8.3,4.0 \mathrm{~Hz}), 2.30$ (m, 1H), 2.05 (ddd, 1H, $J=15.6,9.0,3.1 \mathrm{~Hz}$ ), 1.76-1.43 (m, 4H), 1.55 (d, 3H, $J=7.1 \mathrm{~Hz}), 1.05$ (s, 3H); ${ }^{13} \mathrm{C} \mathrm{NMR}\left(\mathrm{CDCl}_{3}, 50 \mathrm{MHz}\right) \delta \mathrm{ppm}$ : $169.3(\mathrm{C}), 143.7$ (C), 141.2 (C), $128.3(2 \mathrm{CH})$, $126.5(\mathrm{CH}), 126.1(2 \mathrm{CH}), 105.7(\mathrm{CH}), 49.9$ $(\mathrm{CH}), 43.5(\mathrm{C}), 38.3\left(\mathrm{CH}_{2}\right), 33.4\left(\mathrm{CH}_{2}\right), 29.9$ $\left(\mathrm{CH}_{2}\right), 28.5\left(\mathrm{CH}_{2}\right), 21.1\left(\mathrm{CH}_{3}\right), 14.8\left(\mathrm{CH}_{3}\right)$; Anal. calcd for $\mathrm{C}_{17} \mathrm{H}_{21} \mathrm{NO}$ : C, 79.96; H, 8.29; N, 5.49. Found: C, 80.04; H, 8.56; N, 5.15\%.

3-[1-Methyl-2-(1-phenyl-ethylimino)-cyclopentyl]-propionitrile 17c. IR (neat, $v \mathrm{~cm}^{-1}$ ): 3027, 2962, 2867, 2245, 1672; ${ }^{1} \mathrm{H}$ NMR $\left(\mathrm{CDCl}_{3}\right.$, $300 \mathrm{MHz}) \delta: 7.35-7.17(\mathrm{~m}, 5 \mathrm{H}), 4.41(\mathrm{q}, 1 \mathrm{H}, J=$ 6.6 Hz), 2.65-2.27 (m, 4H), 1.94-1.57 (m, 6H), 1.41 (d, 3H, $J=6.6, \mathrm{~Hz}), 1.06$ (s, 3H); ${ }^{13} \mathrm{C} \mathrm{NMR}$ $\left(\mathrm{CDCl}_{3}, 75 \mathrm{MHz}\right) \delta$ ppm: $179.9(\mathrm{C}), 145.8(\mathrm{C})$, $128.2(2 \mathrm{CH}), 126.4(\mathrm{CH}), 126.3(2 \mathrm{CH}), 120.7$ (C), $61.2(\mathrm{CH}), 45.4(\mathrm{C}), 37.1\left(\mathrm{CH}_{2}\right), 35.8\left(\mathrm{CH}_{2}\right)$, $28.5\left(\mathrm{CH}_{2}\right), 24.9\left(\mathrm{CH}_{3}\right), 23.8\left(\mathrm{CH}_{3}\right), 20.5\left(\mathrm{CH}_{2}\right)$, $12.4\left(\mathrm{CH}_{2}\right)$.

3-[1-Methyl-2-(1-phenyl-ethylimino)-cyclohexyl]-propionitrile 18c. IR (neat, $v \mathrm{~cm}^{-1}$ ): 2969, 2931, 2866, 2247, 1705, 1650; ${ }^{1} \mathrm{H}$ NMR $\left(\mathrm{CDCl}_{3}, 300 \mathrm{MHz}\right) \delta \mathrm{ppm}:$ 7.39-7.20 (m, 5H), $4.70(\mathrm{q}, 1 \mathrm{H}, J=6.6 \mathrm{~Hz}), 2.53-2.14(\mathrm{~m}, 5 \mathrm{H})$, 2.13-1.81 (m, 1H), 1.74-1.27 (m, 6H), $1.36(\mathrm{~d}$, $3 \mathrm{H}, J=6.6, \mathrm{~Hz}), 1.04$ (s, 3H); ${ }^{13} \mathrm{C} \mathrm{NMR}\left(\mathrm{CDCl}_{3}\right.$, $75 \mathrm{MHz}) \delta$ ppm: 172.1 (C), 146.6 (C), 128.2 $(2 \mathrm{CH}), 126.4(3 \mathrm{CH}), 121.1(\mathrm{C}), 57.8(\mathrm{CH}), 43.2$ (C), $39.0\left(\mathrm{CH}_{2}\right), 35.2\left(\mathrm{CH}_{2}\right), 27.1\left(\mathrm{CH}_{2}\right), 25.8$ $\left(\mathrm{CH}_{3}\right), 24.9\left(\mathrm{CH}_{2}\right), 23.9\left(\mathrm{CH}_{3}\right), 21.2\left(\mathrm{CH}_{2}\right), 12.4$ $\left(\mathrm{CH}_{2}\right)$.

Methyl (1'S)-3-(1'-Methyl-2'-oxocyclohexyl)propionate $7 \mathrm{~b}$. IR (neat, $v \mathrm{~cm}^{-1}$ ): 2960, 1731, 1437; ${ }^{1} \mathrm{H}$ NMR $\left(200 \mathrm{MHz}, \mathrm{CDCl}_{3}\right) \delta$ ppm: 3.33 (s, 3H), 2.74-2.18 (m, 4H), 1.98-1.62 (m, 6H), $1.01(\mathrm{~s}, 3 \mathrm{H}) ;{ }^{13} \mathrm{C}$ NMR $\left(50 \mathrm{MHz}, \mathrm{CDCl}_{3}\right) \delta \mathrm{ppm}$ : $222.3(\mathrm{C}), 173.8(\mathrm{C}), 51.5\left(\mathrm{CH}_{3}\right), 47.4(\mathrm{C}), 37.3$ $\left(\mathrm{CH}_{2}\right), 35.9\left(\mathrm{CH}_{2}\right), 32.0\left(\mathrm{CH}_{2}\right), 29.2\left(\mathrm{CH}_{2}\right), 21.2$ $\left(\mathrm{CH}_{3}\right), 18.4\left(\mathrm{CH}_{2}\right)$; Anal. for $\mathrm{C}_{10} \mathrm{H}_{16} \mathrm{O}_{3}$, calcd. $\mathrm{C}$, 65.19; H, 8.75; found $\mathrm{C}, 65.08 ; \mathrm{H}, 8.79$; 12a $[\alpha]_{\mathrm{D}}{ }^{20}-34.5\left(\mathrm{c}=2\right.$; EtOHabs); lit. ${ }^{38}$ ent-12a $[\alpha]_{\mathrm{D}}$ $20+35.7\left(\mathrm{c}=2, \mathrm{EtOH}_{\mathrm{abs}}\right)$. 


\section{3-(1-Methyl-2-oxo-cyclopentyl)-propionitrile}

15c. IR (neat, $v \mathrm{~cm}^{-1}$ ): 2965, 2927, 2872, 2247, $1731 ;{ }^{1} \mathrm{H}$ NMR $\left(300 \mathrm{MHz}, \mathrm{CDCl}_{3}\right) \delta \mathrm{ppm}: 2.46-$ 2.14 (m, 4H), 1.97-1.69 (m, 6H), 1.02 (s, 3H); ${ }^{13} \mathrm{C} \mathrm{NMR}\left(75 \mathrm{MHz}, \mathrm{CDCl}_{3}\right) \delta$ ppm: $221.2(\mathrm{C})$, $119.7(\mathrm{C}), 47.2(\mathrm{C}), 37.2\left(\mathrm{CH}_{2}\right), 35.7\left(\mathrm{CH}_{2}\right), 32.0$ $\left(\mathrm{CH}_{2}\right), 20.9\left(\mathrm{CH}_{3}\right), 18.4\left(\mathrm{CH}_{2}\right), 12.4\left(\mathrm{CH}_{2}\right)$; $[\alpha]_{\mathrm{D}}{ }^{20}=-34.6^{\circ}\left(\mathrm{c}=0.003, \mathrm{EtOH}_{\mathrm{abs}}\right)$; Anal. Calcd for $\mathrm{C}_{9} \mathrm{H}_{13} \mathrm{NO}$ : $\mathrm{C}, 71.49 ; \mathrm{H}, 8.67 ; \mathrm{N}, 9.26$; $\mathrm{O}$, 10.58. Found: C, 71.06; H, 8.12; N, 9.07.

\section{3-(1-Methyl-2-oxo-cyclohexyl)-propionitrile}

16c. IR (neat, $v \mathrm{~cm}^{-1}$ ): 2937, 2867, 2246, 1700, 1451; ${ }^{1} \mathrm{H}$ NMR $\left(300 \mathrm{MHz}, \mathrm{CDCl}_{3}\right) \delta$ ppm: 2.48$2.37(\mathrm{~m}, 1 \mathrm{H}), 2.33-2.26(\mathrm{~m}, 3 \mathrm{H}), 1.97-1.64(\mathrm{~m}$, $8 \mathrm{H}), 1.12(\mathrm{~s}, 3 \mathrm{H}) ;{ }^{13} \mathrm{C} \mathrm{NMR}\left(75 \mathrm{MHz}, \mathrm{CDCl}_{3}\right) \delta$ ppm: $214.3(\mathrm{C}), 120.0(\mathrm{C}), 47.6(\mathrm{C}), 38.5\left(2 \mathrm{CH}_{2}\right)$, $33.6\left(\mathrm{CH}_{2}\right), 27.1\left(\mathrm{CH}_{2}\right), 22.2\left(\mathrm{CH}_{3}\right), 20.8\left(\mathrm{CH}_{2}\right)$, $12.3\left(\mathrm{CH}_{2}\right)$; Anal. for $\mathrm{C}_{10} \mathrm{H}_{15} \mathrm{NO}$, calcd. C, 72.69; H, 9.15; found C, 72.23; H, 8.49; MS (ESI): 166 $(\mathrm{M}+1) \mathbf{1 6 c}[\alpha]_{\mathrm{D}}{ }^{24} 9.7\left(\mathrm{c}=0.02, \mathrm{EtOH}_{\mathrm{abs}}\right)$.

\section{[2-(2-Benzenesulfonyl-ethyl)-2-methyl-cyclo-} pentylidene]-(1-phenyl-ethyl)-amine 17d IR (neat, $v \mathrm{~cm}^{-1}$ ): 2962, 1671, 1447, 1305, 1145; ${ }^{1} \mathrm{H}$ NMR $\left(300 \mathrm{MHz}, \mathrm{CDCl}_{3}\right) \delta$ ppm: 7.70-7.45 (m, $10 \mathrm{H}), 4.34(\mathrm{q}, 1 \mathrm{H}, J=6.6 \mathrm{~Hz}), 3.37\left(\mathrm{~m}_{\mathrm{c}}, 2 \mathrm{H}\right)$, 2.24 (bt, $2 \mathrm{H}, J=5.9 \mathrm{~Hz}), 1.80-1.40(\mathrm{~m}, 6 \mathrm{H}), 1.31$ $(\mathrm{d}, 3 \mathrm{H}, J=6.6 \mathrm{~Hz}), 1.00(\mathrm{~s}, 3 \mathrm{H}) ;{ }^{13} \mathrm{C} \mathrm{NMR}(75$ $\left.\mathrm{MHz}, \mathrm{CDCl}_{3}\right) \delta$ ppm: 179.6 (C), 146.0 (C), 138.3 $(\mathrm{CH}), 133.6(\mathrm{CH}), 129.2(2 \mathrm{CH}), 129.1(2 \mathrm{CH})$, $128.1(\mathrm{CH}), 127.7(\mathrm{CH}), 126.2(\mathrm{CH}), 67.8\left(\mathrm{CH}_{2}\right)$, $61.1(\mathrm{CH}), 52.2(\mathrm{C}), 37.6\left(\mathrm{CH}_{2}\right), 28.3\left(\mathrm{CH}_{2}\right)$, $25.5\left(\mathrm{CH}_{2}\right), 25.0\left(\mathrm{CH}_{3}\right), 23.8\left(\mathrm{CH}_{3}\right), 20.4\left(\mathrm{CH}_{2}\right)$.

\section{[2-(2-Benzenesulfonyl-ethyl)-2-methyl-cyclo-} hexylidene]-(1-phenyl-ethyl)-amine 18d IR (neat, $v \mathrm{~cm}^{-1}$ ): 2928, 1707, 1650; ${ }^{1} \mathrm{H}$ NMR (300 $\left.\mathrm{MHz}, \mathrm{CDCl}_{3}\right) \delta$ ppm: 8.00-7.87 (m, 4H), 7.66$7.49(\mathrm{~m}, 6 \mathrm{H}), 4.61$ (q, $1 \mathrm{H}, J=6.6 \mathrm{~Hz}), 3.35-3.20$ (m, 2H), 2.42-2.29 (m, 2H), 2.18-2.00 (m, 2H), 1.90-1.38 (m, 6H), 1.24 (d, 3H, $J=6.6 \mathrm{~Hz}), 1.01$ $(\mathrm{s}, 3 \mathrm{H}) ;{ }^{13} \mathrm{C} \mathrm{NMR}\left(75 \mathrm{MHz}, \mathrm{CDCl}_{3}\right) \delta \mathrm{ppm}$ : $172.2(\mathrm{C}), 146.6(\mathrm{C}), 139.3(\mathrm{C}), 133.4(\mathrm{CH})$,
$129.1(\mathrm{CH}), 128.2(\mathrm{CH}), 126.4(\mathrm{CH}), 57.7(\mathrm{CH})$, $52.2\left(\mathrm{CH}_{2}\right), 43.0(\mathrm{C}), 39.3\left(\mathrm{CH}_{2}\right), 31.9\left(\mathrm{CH}_{2}\right)$, $27.0\left(\mathrm{CH}_{2}\right), 25.7\left(\mathrm{CH}_{3}\right), 24.7\left(\mathrm{CH}_{2}\right), 24.2\left(\mathrm{CH}_{3}\right)$, $21.2\left(\mathrm{CH}_{2}\right)$.

\section{2-(2-Benzenesulfonyl-ethyl)-2-methyl-}

cyclopentanone $15 \mathrm{~d} \mathrm{Mp}=69{ }^{\circ} \mathrm{C}$; IR (neat, $v$ $\left.\mathrm{cm}^{-1}\right): 2965,2870,1729 ;{ }^{1} \mathrm{H}$ NMR $(300 \mathrm{MHz}$, $\left.\mathrm{CDCl}_{3}\right) \delta$ ppm: 7.87 (bd, $2 \mathrm{H}, J=8.3 \mathrm{~Hz}$ ), 7.687.45 (m, 3H), 3.14 (ddd, 1H, $J=18.4,12.0,4.7$ Hz), 2.96 (ddd, 1H, $J=18.4,12.2,4.9$ Hz), 2.352.07 (m, 2H), 1.91-1.72 (m, 6H), 0.94 (s, 3H); ${ }^{13} \mathrm{C}$ NMR (75 MHz, $\left.\mathrm{CDCl}_{3}\right) \delta$ ppm: $221.4(\mathrm{C})$, 138.7 (C), $133.7(\mathrm{CH}), 129.2(2 \mathrm{CH}), 127.9$ $(2 \mathrm{CH}), 51.8\left(\mathrm{CH}_{2}\right), 46.7(\mathrm{C}), 37.2\left(\mathrm{CH}_{2}\right), 36.2$ $\left(\mathrm{CH}_{2}\right), 28.9\left(\mathrm{CH}_{2}\right), 21.0\left(\mathrm{CH}_{3}\right), 18.4\left(\mathrm{CH}_{2}\right)$; $[\alpha]_{\mathrm{D}}^{23}=-19.4^{\circ}\left(\mathrm{c}=0.0075, \mathrm{EtOH}_{\mathrm{abs}}\right) ; \mathrm{MS}$ (APCI): m/z 267 (100\%) [M + H] $]^{+}$; Anal. Calcd for $\mathrm{C}_{14} \mathrm{H}_{18} \mathrm{O}_{3} \mathrm{~S}$ : C, 63.13; $\mathrm{H}, 6.81 ; \mathrm{O}, 18.02 ; \mathrm{S}$, 12.04. Found: C, $62.65 ; \mathrm{H}, 6.80$.

\section{2-(2-Benzenesulfonyl-ethyl)-2-methyl-} cyclohexanone 16d $\mathrm{Mp}=74-77^{\circ} \mathrm{C}$; IR (neat, $v$ $\mathrm{cm}^{-1}$ ): 2934, 2868, 1700; ${ }^{1} \mathrm{H}$ NMR $(300 \mathrm{MHz}$, $\left.\mathrm{CDCl}_{3}\right) \delta$ ppm: 7.86 (bd, $2 \mathrm{H}, J=8.3 \mathrm{~Hz}$ ), 7.65$7.49(\mathrm{~m}, 3 \mathrm{H}), 3.06(\mathrm{ddd}, 1 \mathrm{H}, J=13.7,11.9,5.0$ Hz), 2.98 (ddd, 1H, $J=13.7,11.7,5.0 \mathrm{~Hz}$ ), 2.39$2.13(\mathrm{~m}, 2 \mathrm{H}), 2.00-1.88(\mathrm{~m}, 1 \mathrm{H}), 1.79-1.55(\mathrm{~m}$, $7 \mathrm{H}), 1.01(\mathrm{~s}, 3 \mathrm{H}) ;{ }^{13} \mathrm{C} \mathrm{NMR}\left(75 \mathrm{MHz}, \mathrm{CDCl}_{3}\right) \delta$ ppm: $214.3(\mathrm{C}), 138.9$ (C), $133.6(\mathrm{CH}), 129.2$ $(2 \mathrm{CH}), 127.9(2 \mathrm{CH}), 51.8\left(\mathrm{CH}_{2}\right), 47.4(\mathrm{C}), 38.9$ $\left(\mathrm{CH}_{2}\right), 38.4\left(\mathrm{CH}_{2}\right), 30.2\left(\mathrm{CH}_{2}\right), 27.1\left(\mathrm{CH}_{2}\right), 22.3$ $\left(\mathrm{CH}_{3}\right), 20.8\left(\mathrm{CH}_{2}\right) ;[\alpha]_{\mathrm{D}}{ }^{24}=+2.9^{\circ}(\mathrm{c}=0.01$, $\mathrm{EtOH}_{\text {abs. }}$; MS (APCI): m/z 281 (100\%) [M+ $\mathrm{H}]^{+}$; Anal. Calcd for $\mathrm{C}_{15} \mathrm{H}_{20} \mathrm{O}_{3} \mathrm{~S}: \mathrm{C}, 64.26 ; \mathrm{H}$, 7.19; O, 17.12; S, 11.44. Found: C, 64.40; H, 7.03 .

General procedure for the synthesis of ketoacid 6

A mixture of adduct $\mathbf{6 a}$ (452 $\mathrm{mg}, 2 \mathrm{mmol}$ ) and formic acid $(2 \mathrm{~mL})$ was stirred at $20{ }^{\circ} \mathrm{C}$ for $2 \mathrm{~h}$. Formic acid was distilled, the crude was taken up in $\mathrm{Et}_{2} \mathrm{O}(10 \mathrm{~mL})$, washed with saturated $\mathrm{NaHCO}_{3}$ 
solution $(2 \times 10 \mathrm{~mL})$. The aqueous layer was acidified at $0{ }^{\circ} \mathrm{C}(6 \mathrm{~N} \mathrm{HCl})$ and thoroughly extracted (4 $\left.\begin{array}{lllll}4 & 10 & \mathrm{~mL} & \mathrm{Et}_{2} \mathrm{O}\end{array}\right)$. The combined organic phase was dried $\left(\mathrm{MgSO}_{4}\right)$ and filtered $\left(\right.$ Celite $\left.^{\circledR}\right)$ and the crude concentrated in vacuo to give keto acid 6a (302 mg, 89\%) as a colorless oil. This material was used without further purification in the next step.

(1'S)-3-(1'-Methyl-2-oxocyclopentyl)-

propionic acid 6a. IR (neat, $v \mathrm{~cm}^{-1}$ ): 3512, 3090,2963, 2873, 2663, 1729, 1706; ${ }^{1} \mathrm{H}$ NMR $\left(200 \mathrm{MHz}, \mathrm{CDCl}_{3}\right) \delta \mathrm{ppm}: 11.0(\mathrm{bs}, 1 \mathrm{H}), 1.67-$ 1.33 (m, 4H), 1.19-0.81 (m, 6H), 0.20 (s, 3H); ${ }^{13} \mathrm{C}$ NMR $\left(50 \mathrm{MHz}, \mathrm{CDCl}_{3}\right) \delta$ ppm: $222.8(\mathrm{C})$, $178.3(\mathrm{C}), 47.0(\mathrm{C}), 36.8\left(\mathrm{CH}_{2}\right), 35.4\left(\mathrm{CH}_{2}\right), 30.6$ $\left(\mathrm{CH}_{2}\right), 28.7\left(\mathrm{CH}_{2}\right), 20.7\left(\mathrm{CH}_{3}\right), 18.0\left(\mathrm{CH}_{2}\right)$; Anal. for $\mathrm{C}_{9} \mathrm{H}_{14} \mathrm{O}_{3}$, calcd. $\mathrm{C}, 63.51 ; \mathrm{H}, 8.29$; found $\mathrm{C}$, 63.28; H, 8.39; $[\alpha]^{25} \mathrm{D}-40.6$ (c=1.6, EtOH $\left.{ }_{a b s}\right)$.

\section{(1'S)-3-(1'-Methyl-2-oxocyclohexyl)-}

propionic acid $6 \mathbf{b}$. IR (neat, $v \mathrm{~cm}^{-1}$ ): 3502, 2935, 2866, 1700; ${ }^{1} \mathrm{H}$ NMR (300 MHz, $\left.\mathrm{CDCl}_{3}\right) \delta$ ppm: 9.4 (bs, $1 \mathrm{H}), 2.38-2.29(\mathrm{~m}, 3 \mathrm{H}), 2.23-2.12(\mathrm{~m}$, $1 \mathrm{H}), 2.03-1.93(\mathrm{~m}, 1 \mathrm{H}), 1.84 .68(\mathrm{~m}, 6 \mathrm{H}), 1.62-$ $158(\mathrm{~m}, 1 \mathrm{H}), 1.05(\mathrm{~s}, 3 \mathrm{H}) ;{ }^{13} \mathrm{C} \mathrm{NMR}(75 \mathrm{MHz}$, $\left.\mathrm{CDCl}_{3}\right) \delta$ ppm: $215.5(\mathrm{C}), 179.3(\mathrm{C}), 47.7(\mathrm{C})$, $39.0\left(\mathrm{CH}_{2}\right), 38.5\left(\mathrm{CH}_{2}\right), 32.2\left(\mathrm{CH}_{2}\right), 28.9\left(\mathrm{CH}_{2}\right)$, $27.3\left(\mathrm{CH}_{2}\right), 22.3\left(\mathrm{CH}_{3}\right), 20.8\left(\mathrm{CH}_{2}\right) ; \mathrm{MS}(\mathrm{ESI})$ $207(\mathrm{M}+23) 391(2 \mathrm{M}+23) ;[\alpha]^{28} \mathrm{D}-85(\mathrm{c}=0.13$, $\left.\mathrm{EtOH}_{\mathrm{abs}}\right)$.

Chemical correlation to Methyl (1'S)-3-(1Methyl-2-oxo-cyclopentyl)-propionate 7a: A $0.5 \mathrm{M}$ solution of diazomethane in $\mathrm{Et}_{2} \mathrm{O}(5 \mathrm{~mL})$ was added to a solution of the acid $6(97 \mathrm{mg}$, $0.57 \mathrm{mmol})$ in dry $\mathrm{Et}_{2} \mathrm{O}(20 \mathrm{~mL})$ at $0{ }^{\circ} \mathrm{C}$. The resulting mixture was stirred at room temperature for 2 hours and the excess of diazomethane was destroyed with acetic acid. The reaction mixture was washed with brine $(2 \times 5 \mathrm{~mL})$, dried $\left(\mathrm{MgSO}_{4}\right)$, and concentrated in vacuo. The residue was purified by column chromatography (cyclohexane/AcOEt, 9:1) to give methyl ester
$7 \mathbf{a}$ as a colourless oil $(100 \mathrm{mg}, 95 \%) ;[\alpha]^{20}-$ 32.5 (c = 2; EtOHabs); lit. ${ }^{10}$ ent-12a $[\alpha]_{\mathrm{D}}{ }^{20}+35.7$ $\left(\mathrm{c}=2, \mathrm{EtOH}_{\mathrm{abs}}\right)$.

3b. Enantiomeric excess determination: For ${ }^{13} \mathrm{C}-\left\{{ }^{1} \mathrm{H}\right\}$ 1D NMR experiments in polypeptidic oriented solvents, the sample preparation consisted of directly weighting 25-30 $\mathrm{mg}$ of solute, around $140 \mathrm{mg}$ of poly- $\gamma$-benzyl-Lglutamate (PBLG, DP $=463$, commercially available) and adding about $350 \mathrm{mg}$ of dichloromethane into a $5 \mathrm{~mm}$ NMR tube. Under these conditions, the total volume of the sample is optimal compared to the length of the coil of a $5 \mathrm{~mm}$ diameter probe-head. Compared to previous work, we have used a larger amount of PBLG than usual $(100 \mathrm{mg})$ in order to obtain a clean liquid crystalline phase. This is a consequence of the relatively low degree of polymerization $(\mathrm{DP}=463$, i.e. $\mathrm{MW} \approx 101000$ g. $\left.\mathrm{mol}^{-1}\right)$. The exact composition of each NMR sample is given in Table 3 . To avoid the evaporation of dichloromethane during long NMR experimental time, we have sealed the samples. Note here that a mixture of protonated and deuterated dichloromethane was used. This solution allows to easily shim the magnet on the proton FID as well as to minimize the digitization problems associated with the dynamic range of the Analogue-to-Digital Converter (ADC) induced by the difference of ${ }^{13} \mathrm{C}$ signal intensity between dichloromethane and solute. In other hands, the shape and the line width of ${ }^{13} \mathrm{C}$ resonances of dichloromethane provide a serious control of the magnet stability as well as possible time-evolution of the sample homogeneity during the experiments. The sample is then centrifuged during few seconds, then inverted and centrifuged again. This process is repeated until an optically homogeneous birefringent phase is obtained. 
Table 3. Composition of liquid-crystalline representative NMR samples investigated

\begin{tabular}{ccccc}
\hline Sample & Solute & $\begin{array}{c}\text { Solute } \\
/ \mathrm{mg}^{a}\end{array}$ & $\begin{array}{c}\text { Co- } \\
\text { solvent } \\
/ \mathrm{mg}^{a}\end{array}$ & $\begin{array}{c}\text { Polymer } \\
\% \text { in } \\
\text { weight }\end{array}$ \\
\hline 1 & $($ rac $)-6$ & 27 & $75 / 275$ & 27.1 \\
2 & $(S)-6$ & 28 & $75 / 277$ & 26.9 \\
3 & $(S)-6$ & 28 & $75 / 277$ & 27.1 \\
\hline
\end{tabular}

Conditions: Polymeric solvent: PBLG; Degree of polymerization of polypeptide used: 463; Cosolvent: $\mathrm{CH}_{2} \mathrm{Cl}_{2}$ / $\mathrm{CD}_{2} \mathrm{Cl}_{2}$; Polymer/mg: $140 ;{ }^{a} \mathrm{The}$ accuracy on the weighing is $1 \mathrm{mg}$.

The NMR tube was not spun in the magnet and its temperature was regulated carefully at $299 \mathrm{~K}$ using the standard variable temperature control unit (BVT 3000). ${ }^{13} \mathrm{C}$ spectra were recorded by adding 1000 to 3000 scans. Gaussian filtering was applied to improve the spectral separation of resonances. The area measurement was performed using a curve fitting algorithm based on complex least squares treatment of the ${ }^{13} \mathrm{C}$ NMR signals with and without filtering. Note that the experiments and the area measurements were repeated several times to estimate accurately the error on the enantiomeric excess of the mixture.

3c. GC-MS mechanistic studies: An HP 5989A GC-MS system (Hewlett-Packard, Palo Alto, CA, USA) was used. The chromatographic separation was performed with an Omega delta-3 capillary column (length: $25 \mathrm{~m}$; I.D. $0.20 \mathrm{~mm}$; film thickness: $0.2 \mu \mathrm{m}$ ) (Macherey-Nagel, Düren, Germany ). In view of comparison, samples consisting of either the asymmetric Michael addition reaction mixture [1 equiv. chiral imine (2a) and 1.1 equiv. tert-butyl acrylate (3)] or each of the individual components (tert-butyl acrylate (3), chiral imine (2a), 2-methyl cyclopentanone 1a, 1phenylethylamine, 2-methyl-2-propanol) were separately irradiated at $100 \mathrm{~W}$ and $200{ }^{\circ} \mathrm{C}$ for 30 min in $10 \mathrm{~mL}$ teflon sealed glass vials and cooled to r.t. prior to GC-mass analysis. The teflon sealed glass vials filled with the reaction medium were maintained at $70^{\circ} \mathrm{C}$ during 15 minutes prior analysis and immediately processed. The head space $(5 \mu \mathrm{L})$ was sampled using an airtight syringe and injected in splitless mode. Helium pressure was $50 \mathrm{kPa}$. The injector temperature was $250{ }^{\circ} \mathrm{C}$ and the initial oven temperature was $35{ }^{\circ} \mathrm{C}$. This temperature was maintained for 1 min, the temperature was then programmed as follows: $4{ }^{\circ} \mathrm{C} / \mathrm{min}$ up to $50{ }^{\circ} \mathrm{C}$ then $6{ }^{\circ} \mathrm{C} / \mathrm{min}$ up to $100^{\circ} \mathrm{C}$ followed by a $5 \mathrm{~min}$ hold. The transfer line temperature was set to $280^{\circ} \mathrm{C}$. Analysis was performed by electronic impact ionisation. The ion source and quadrupole temperature was set to $200{ }^{\circ} \mathrm{C}$ and $100{ }^{\circ} \mathrm{C}$ respectively. The electron energy was $70 \mathrm{eV}$. Acquisition was performed in scan mode over the range of 20 to 150 at a scan rate of $0.9 \mathrm{scan} / \mathrm{sec}$ (4 samplings per scan). Analysis of the results obtained for the head space of the asymmetric Michael reaction showed that the peak observed at $1.605 \mathrm{~min}$ correspond to 2-methyl-2-butene ( $\mathrm{MW}=56$ g.mol ${ }^{-1}$, identical fragmentation and comparable abundances) $)^{17}$ A similar peak was not detected from the head space of the other samples, except for the tert-butyl acrylate $\left(\mathrm{MW}=128 \mathrm{~g} \cdot \mathrm{mol}^{-1}\right.$ ) one. However, ions at $\mathrm{m} / \mathrm{z} 55,57$ and 59 are not present in the same ratio for the 2-methyl-2butene mass spectrum. Moreover, analysis of the tert-butanol $\left(\mathrm{MW}=74 \mathrm{~g} \cdot \mathrm{mol}^{-1}\right)$ sample indicates that in the reaction conditions, tert butanol did not led to 2-methyl-2-butene. This set of results gave evidence that 2-methyl-2-butene and not tert-butanol was released during the lactamization process of Michael adduct (5) (see article, Scheme 3).

3d. Theroretical calculations: Geometries for the reactants were optimized by means of 
gradient technique at RHF AM1 level ${ }^{20}$ by using the semi-empirical molecular orbital program MOPAC. $^{21}$ All the RHF AM1 transition structures were located using the procedures implemented in MOPAC (Version 5.0). All variables were optimized by minimizing the sum of the squared scalar gradients (NLLSQ and
SIGMA) ${ }^{22,23}$ Force calculations were carried out to ensure that the transition structures located had one imaginary frequency. Final values of the gradient norms were $<1 \mathrm{kcal} / \AA \AA$ and each transition structure had one negative eigenvalue in the Hessian matrix as required.

\section{Conclusions}

In conclusion, we have demonstrated that the reaction of hindered tert-butyl acrylate $\mathbf{2}$ in the AMACI was efficiently promoted under $\mu \mathrm{W}$ activation, compared to conventional heating. As expected, regardless the activation mode, the control of the stereochemistry of the newly created quaternary carbon center in such Michael adducts is always dictated by the configuration of the chiral inductor. The stereoselectivity of the process was determined using natural abundance ${ }^{13} \mathrm{C}-\left\{{ }^{1} \mathrm{H}\right\}$ NMR in a chiral polypeptide liquid crystal. Moreover, the temperature profiles achieved under microwave irradiation are not accessible in conventional heating and can allow a differentiation in the reaction pathways. A direct and stereoselective access to lactams $\mathbf{8}$ was thus achieved only under $\mu \mathrm{W}$, although in moderate yield. A highly stereoselective process (ee $>95 \%$ ) was obtained either at $100^{\circ} \mathrm{C}$ for $4 \mathrm{~h}(\Delta)$ or for 30 $\min (\mu \mathrm{W}, 100 \mathrm{~W})$. A good correlation was obtained between experiment and theoretical calculations. Both the more polar and asynchronous transition state led to the expected Michael adduct $(S) \mathbf{- 4}$, and are favored under $\mu \mathrm{W}$ activation, allowing the reaction to proceed efficiently in minutes. Finally, Michael adducts from methyl acrylate, benzyl acrylate, vinylsulfone and acrylonitrile are regio- and stereoselectively obtained in high yield and short time using the microwave process.

\section{Acknowledgments}

We thank Dr Kathalyn L. Serre, Hanaa Tagzhouty and Kristine Aerola (BioCIS) for preliminary experiments, Sophie Mairesse-Lebrun for performing the microanalysis, CNRS and MENRS for financial support and CEM for technical support to A. L.

\section{Author Contributions}

Françoise Dumas ensure the conception and design of the chemistry and Philippe Lesot the the enantiomeric purity determination using natural abundance ${ }^{13} \mathrm{C}-\left\{{ }^{1} \mathrm{H}\right\}$ NMR. Lucie Vandromme, Li Chen and Lai Wei performed the chemical experiments and analyzed the data, Franck Le Bideau, and Françoise Dumas wrote the manuscript, André Loupy helped and advised us for the microwave chemistry, Olivier Lafon and Philippe Lesot were in charge of the NMR determination of selectivity in chiral liquid phase, Elise Tran Huu Dau performed the theoretical calculations and Pierre Chaminade the CPV analysis.

\section{Conflicts of Interest}

The authors declare no conflict of interest.

\section{References and Notes}

1. Denissova, I.; Barriault, L. Stereoselective formation of quaternary carbon centers and related fucntions. Tetrahedron report number 661, Tetrahedron 2003, 59, 10105-10146. (b) Quaternary 
Stereocenters: Challenge and Solutions for Organic Synthesis (Eds.: J. Christoffers, A. Baro), Wiley-VCH, Weinheim, Germany, 2005.

2. Reviews: (a) d'Angelo, J.; Desmaële, D.; Dumas, F.; Guingant, A. The asymmetric Michael addition reactions using chiral imines. Tetrahedron: Asymmetry 1992, 3, 459-505. (b) d'Angelo, J.; Cavé, C.; Desmaële, D.; Dumas, F. The Asymmetric Michael Addition Reactions Using Chiral Imines: Application to the synthesis of Compounds of Biological Interest. in Trends in Organic Chemistry Pandalai S. G. Ed.; Transworld Research Network, Trivandrum, India 1993, volume 4, pp 555-616.

3. See for example: (a) Pizzonero, M.; Dumas, F.; d'Angelo, J. Enantioselective Synthesis of (R)-1Azaspiro[4.4]nonane-2,6-dione Ethylene Ketal, Key Chiral Intermediate in the Elaboration of (-)Cephalotaxine. Heterocycles 2005, 66, 31-37. (b) Kousara, M.; Ferry, A.; Le Bideau, F.; Serré, K. L.; Chataigner, I.; Morvan, I.; Dubois, J.; Chéron, M.; Dumas, F. First enantioselective total synthesis and configurational assignments of suberosenone and suberosanone as potential antitumor agents. Chem. Commun., 2015, 51, 3458-3461. (c) Ito, F.; Ohbatake, Y.; Aoyama, S.; Ikeda, T.; Arima, S.; Yamada, Y.; Ikeda, H.; Nagamitsu, T.: Total Synthesis of (+)-Clavulatriene A. Synthesis 2015, 47, 1348-1355.

4. Sevin, A.; Tortajada, M., Pfau, M. Toward a transition-state model in the asymmetric alkylation of chiral ketone secondary enamines by electron-deficient alkenes. A theoretical MO study. J. Org. Chem. 1986, 51, 2671-2675. (b) Lucero, M. J.; Houk, K. N. Conformational Transmission of Chirality: The Origin of 1,4-Asymmetric Induction in Michael Reactions of Chiral Imines. J. Am. Chem. Soc. 1997, 119, 826-827. (b) Tran Huu Dau, M. E.; Riche, C.; Dumas, F.; d'Angelo, J. The origin of the stereoselectivity in the asymmetric Michael reaction using chiral imines/secondary enamines under neutral conditions: a computational investigation. Tetrahedron: Asymmetry 1998, 9, 1059-1064 and quoted references.

5. See interalia: (a) Camara, C.; Joseph, D.; Dumas, F.; d'Angelo, J.; Chiaroni, A. High pressure activation in the asymmetric Michael addition of chiral imines to alkyl and aryl crotonates Tetrahedron Lett. 2002, 43, 1445-1448. (b) Camara, C.; Keller, L.; Jean-Charles, K.; Joseph, D.; Dumas, F. A comparative study of high pressure versus other activation modes in the asymmetric Michael reaction of chiral imines. Int. J. High Press. Res. 2004, 24, 149-162.

6. (a) Perreux, L.; Loupy, A. Tetrahedron Report number 588, A tentative rationalization of microwave effects in organic synthesis according to the reaction medium, and mechanistic considerations. Tetrahedron, 2001, 57, 9199-9223. (b) Kappe, C. O. Controlled microwave heating in modern organic synthesis. Angew. Chem. Int. Ed. 2004, 43, 6250-6284. (c) De la Hoz, A.; Diaz-Ortiz, A.; Moreno, A. Microwaves in organic synthesis. Thermal and non-thermal microwave effects. Chem. Soc. Rev. 2005, 34, 164-178. (d) Microwave Heating as a Tool for Sustainable Chemistry; Leadbeater, N. E., Ed.; CRC Press: Boca Raton, FL, USA, 2011. (e) Kappe, C. O.; Stadler, A.; Dallinger, D. Microwaves in Organic and Medicinal Chemistry, 2nd ed.; Wiley-VCH: Weinheim, Germany, 2012. (f) Microwaves in Organic Synthesis, 3rd ed.; De La Hoz, A., Loupy, A., Eds.; Wiley-VCH: Weinheim, Germany, 2013.

7. (a) Loupy, A.; Perreux, P.; Liagre, M.; Burle, K.; Moneuse, M. Reactivity and selectivity under microwaves in organic chemistry. Relation with medium effects and reaction mechanisms. Pure 
Appl. Chem., 2001, 73, 161-166. (b) De la Hoz, A.; Diaz-Ortiz, A.; Moreno, A. Selectivity in organic synthesis under microwave irradiation. Current Org. Chem. 2004, 8, 903-918. (c) Strauss, C. R.; Rooney, D. W, Accounting for clean, fast and high yielding reactions under microwave conditions. Green Chem., 2010, 12, 1340-1344. (d) See for example: Yus, M.; Foubelo, F.; Jesús García-Muñoz, M. Stereoselective Aza-Henry Reaction of Chiral tert-Butanesulfinyl Imines with Methyl or Ethyl 4-Nitrobutanoate: Easy Access to Enantioenriched 6-Substituted Piperidine-2,5diones. Heterocycles 2015, 90, 1419-1432.

8. (a) Langa, F.; De la Cruz, P.; De la Hoz, A.; Diaz-Ortiz, A.; Diez-Barra, E. Microwave irradiation: more than just a method for accelerating reactions. Contemp. Org. Synth. 1997, 4, 373-386. (b) Manhas, M. S.; Banik, B. K.; Mathur, A.; Vincent, J. E.; Bose, A. K. Vinyl- $\beta$ lactams as Efficient Synthons. Eco-friendly Approaches via Microwave Assisted Reactions. Tetrahedron 2000, 56, 5587-5601. (c) Camara, C.; Keller, L.; Dumas, F. Microwave activation of an asymmetric Michael reaction: unexpected behavior of chiral $\alpha$-alkoxy imines. Tetrahedron: Asymmetry 2003, 14, 3263-3266. (d) Narasimhan, S.; Velmathi, S. Effect of Microwaves in the Chiral Switching Asymmetric Michael Reaction Molecules, 2003, 8, 256-262. (e) Escalante, J.; Díaz-Coutiño, F. D. Synthesis of $\gamma$-Nitro Aliphatic Methyl Esters Via Michael Additions Promoted by Microwave Irradiation. Molecules 2009, 14, 1595-1604. (f) Worzakowska, M. Thermal properties of neryl long-chain esters obtained under microwave irradiation. J. Thermal Anal. Calor. 2015, 120, 1715-1722.

9. (a) Kang, J. Y.; Carter, R. G. Primary Amine, Thiourea-Based Dual Catalysis Motif for Synthesis of Stereogenic, All-Carbon Quaternary Center-Containing Cycloalkanones Org. Lett. 2012, 14, 3178-3181. (b) Horinouchi, R.; Kamei, K.; Watanabe, R.; Hieda, N.; Tatsumi, N.; Nakano, K.; Ichikawa, Y.; Kotsuki, H. Enantioselective Synthesis of Quaternary Carbon Stereogenic Centers through the Primary Amine-Catalyzed Michael Addition Reaction of $\alpha$-Substituted Cyclic Ketones at High Pressure. Eur. J. Org. Chem. 2015, 4457-4463.

10. Pfau, M.; Revial, G.; Guingant, A.; d'Angelo, J. Enantioselective synthesis of quaternary carbon centers through Michael-type alkylation of chiral imines. J. Am. Chem. Soc. 1985, 107, 273-274.

11. 1-Phenylethylamine ( $99 \%$ ee) was used to direct the regio and stereoselectivity of the Michael addition and additionnaly served as a chirality marker in the product $\mathbf{4}$, allowing determination of the diastereoselectivity of the reaction using NMR, and by consequence of the enantioselectivity of the Michael process.

12. Sarfati, M.; Lesot, P.; Merlet, D.; Courtieu, J. Theoretical and experimental aspects of enantiomeric differentiation using natural abundance multinuclear NMR spectroscopy in chiral polypeptide liquid crystals. Chem. Commun. 2000, 2069-2081.

13. Meddour, A.; Berdagué, P.; Hedli, A.; Courtieu J.; Lesot, P. Proton-Decoupled Carbon-13 NMR Spectroscopy in a Lyotropic Chiral Nematic Solvent as an Analytical Tool for the Measurement of the Enantiomeric Excess. J. Am. Chem. Soc. 1997, 119, 4502-4508.

14. (a) Lesot ${ }_{2}$ P.; Sarfati, M.; Courtieu, J.; Natural abundance deuterium NMR spectroscopy in polypeptide liquid crystals as a new and incisive means for the enantiodifferentiation of chiral hydrocarbons. Chemistry 2003, 14, 1724-1745. (b) Luy, B. Disinction of enantiomers by NMR spectroscopy using chiral orienting media, J. Indian Inst. Sci., 2010, 90, 119-132. (c) Lesot, P.; 
Aroulanda, C.; Zimmermann, H.; Luz, Z. Enantiotopic discrimination in the NMR spectrum of prochiral solutes in chiral liquid crystals. Chem. Soc. Rev., 2015, 44, 2330-2375.

15. See in relation (a) Tan, K.; Alvarez, R.; Nour, M.; Cavé, C.; Chiaroni, A.; Riche, C.; d'Angelo, J. Racemization processes at a quaternary carbon center in the context of the asymmetric Michael reaction. Tetrahedron Lett. 2001, 42, 5021-5023. (b) Pizzonero, M.; Hendra, F.; Delarue-Cochin, S.; Tran Huu Dau, M.-E.; Dumas, F.; Cavé, C.; Nour, M.; d'Angelo, J. The asymmetric Michaeltype alkylation of chiral $\beta$-enamino esters: critical role of a benzyl ester group in the racemization of adducts. Tetrahedron: Asymmetry 2005, 16, 3853-3857.

16. Design and evaluation of improved magnetic stir bars for single-mode microwave reactors Obermayer, D.; Damm, M.; Kappe, C. O. Org. Biomol. Chem. 2013, 11, 4949-4956.

17. Derivative spectra were compared with those in the NBS75K database (provided by Hewlett Packard with the GC/MS control and data processing software).

18. Kappe, C. O.; Pieber, B.; Dallinge, D. Microwave Effects in Organic Synthesis: Myth or Reality? Ang. Chem. Int. Ed. 2013, 52, 1088-1094.

19. Chemical quantum calculations related to experimental results have shown that $\mu \mathrm{W}$ effects are increasing with the asynchronous character of a mechanism. See for example: (a) Diaz-Ortiz, A.; Carrillo, J. R.; Cossio, F. P.; Gomez-Escalonilla, M. J.; De La Hoz, A.; Moreno, A.; Prieto, P. Synthesis of Pyrazolo[3,4-b]pyridines by Cycloaddition Reactions under Microwave Irradiation. Tetrahedron 2000, 56, 1569-1577. (b) Loupy, A.; Maurel, F.; Sabatie-Gogova, A. Improvements in Diels-Alder cycloadditions with some acetylenic compounds under solvent-free microwaveassisted conditions: experimental results and theoretical approaches. Tetrahedron 2004, 60, 16831691. (c) Langa, F.; de la Cruz, P.; de la Hoz, A.; Espildora, E.; Cossio, P.; Lecea, B. Modification of Regioselectivity in Cycloadditions to $\mathrm{C}_{70}$ under Microwave Irradiation. J. Org Chem. 2000, 65, 2499-2507.

20. Dewar, M. J. S.; Zoebisch, E. G.; Healy, E. F.; Stewart, J. P. P. Development and use of quantum mechanical molecular models. 76. AM1: a new general purpose quantum mechanical molecular model. J. Am. Chem. Soc. 1985, 107, 3902-3909.

21. Stewart, J. P. P. Quantum Chemistry Program Exchange, University of Indiana, Bloomington, U.S.A.; Program 455.

22. Bertels, R. H.; Report CNA-44, 1972, University of Texas, Center for numerical analysis.

23. McIver, J. W.; Komornicki, A. Structure of transition states in organic reactions. General theory and an application to the cyclobutene-butadiene isomerization using a semiempirical molecular orbital method. J. Am. Chem. Soc. 1972, 94, 2625-2633.

(C) 2015 by the authors; licensee MDPI, Basel, Switzerland. This article is an open access article distributed under the terms and conditions defined by MDPI AG, the publisher of the Sciforum.net platform. Sciforum papers authors the copyright to their scholarly works. Hence, by submitting a paper to this conference, you retain the copyright, but you grant MDPI AG the non-exclusive and unrevocable license right to publish this paper online on the Sciforum.net platform. This means you can easily submit your paper to any scientific journal at a later stage and transfer the copyright to its publisher (if required by that publisher). (http://sciforum.net/about ). 